\title{
Ecology and ecophysiology of circum-Mediterranean firs in the context of climate change
}

\author{
Gilbert Aussenac* \\ UMR Écologie, Écophysiologie forestière, INRA - UHP Nancy, 54280 Champenoux, France
}

(Received 19 September 2001; accepted 26 March 2002)

\begin{abstract}
In the expected climatic change scenario (with increased temperatures and water deficits) related to greenhouse effect phenomena, questions are being raised concerning the migration of the potential range of forest specie (contraction in the south and at lower altitudes, extension towards the north and higher altitudes) and the consequences on silviculture. To answer these questions, information about climatic changes and the ecophysiology of the forest species concerned is required. In this paper the case of circum-Mediterranean firs is examined as they could be in danger in parts of their present range but could also provide valuable solutions for the replacement of other species in more northerly zones with temperate humid climates and that would not be adapted to new climatic conditions. We try to answer these questions using a simplified climatic analysis of the original ranges and knowledge about the ecology and ecophysiology of firs. In the original ranges of these species climatic data is rare and very incomplete. Under these conditions it is impossible to undertake a detailed climatological analysis. Also, taking into account the diversity and heterogeneity of the climatic descriptions made by the various authors, and so as to be able to compare the different firs species, we used an aridity index. By taking a numerical approach, this index allowed us to have a general and comparative view of the climatology of the original fir ranges in relation to drought problems, and also to simulate evolution easily and compare it with the present situations for each species. On the basis of all the different results obtained it seems that, in relation to a possible increase in drought linked to a temperature increase (except no doubt for Abies numidica and A. pinsapo), there is a great risk that the present ranges of circum-Mediterranean firs will decrease in the lowest zones of their range, but also in other zones characterized by southerly aspects and shallow soils. For Abies cephalonica and Abies cilici$c a$, species with early bud burst, there is also the risk of a possible increase in late frost damage in addition to water stress effects. Except for $A$. nordmanniana and A. bornmulleriana, other species may also be concerned, but to a lesser extent. Regarding the replacement of species, which would become necessary in the case of climatic change, with the exceptions of A. nordmanniana which has already been used and of for $A$. nebrodensis, these firs could be an alternative to the regression of more hygrophilous species, especially in zones to the north of their present ranges.
\end{abstract}

\section{Abies / circum-Mediterranean firs / climate change / ecology / ecophysiology}

Résumé - Écologie et écophysiologie des sapins circum-méditerranéens dans le contexte du changement climatique. Dans un scénario de changements climatiques attendus (augmentation des températures et des déficits hydriques) liés aux phénomènes d'effet de serre, se pose la question du déplacement de l'aire potentielle des essences forestières (contraction dans la partie sud et à basse altitude et extension vers le nord et en altitude) et de ses conséquences en matière de sylviculture. La réponse à cette question suppose à la fois des informations sur les évolutions climatiques et sur l'écologie et l'écophysiologie des essences forestières concernées. Dans cet article, on aborde le cas des sapins circum-méditerranéens qui pourraient à la fois se trouver menacés dans certaines parties de leur aire actuelle et constituer des solutions valables pour le remplacement d'autres espèces actuellement dans des zones plus septentrionales à climats tempérés humides et qui ne seraient plus adaptés aux nouvelles conditions climatiques. On essaye de répondre à ces questions à partir d'une analyse climatique simplifiée des aires d'origine et de la connaissance de l'écologie et de l'écophysiologie de ces sapins. Dans les aires d'origines occupées par ces espèces, les données climatologiques sont rares et très incomplètes, dans ces conditions il est impossible de faire une étude climatologique approfondie. Aussi, compte tenu de la diversité et de l'hétérogénéité des descriptions des climats par les différents auteurs, et pour pouvoir comparer les différentes espèces de sapins, on a utilisé un indice d'aridité qui a permis par une approche numérique, d'une part d'avoir une vue générale et comparée sur la climatologie des aires d'origine des sapins, par rapport aux problèmes de sécheresse et d'autre part de pouvoir simuler facilement des évolutions climatiques et pour chaque espèce de les comparer aux situations actuelles. Sur la base de l'ensemble des différents résultats obtenus, il apparait qu'en relation avec un accroissement éventuel de la sécheresse, lié à une augmentation de la température et à l'exception sans doute d'Abies numidica et

\footnotetext{
* Correspondence and reprints

Tel.: 03833940 25; fax: 03833940 69; e-mail: aussenac@nancy.inra.fr
} 
A. pinsapo, des risques importants de régression des aires actuelles des sapins circum-méditerranéens existent dans les zones les plus basses de leur aire, mais aussi dans les expositions sud et sur des sols très superficiels. Pour Abies cephalonica et Abies cilicica, espèces à débourrement très précoce, il y a aussi un risque d'accroissement possible des dégâts de gelées tardives qui s'ajouterait aux effets du stress hydrique. À l'exception, d'A. nordmanniana et A. bornmulleriana, les autres espèces pourraient aussi êtres concernées mais à un moindre degré de gravité. Au plan du remplacement d'espèces, qui serait rendu nécessaire par le changement climatique, on peut dire que ces sapins, outre A. nordmanniana déjà utilisé et à l'exception de $A$. nebrodensis, pourraient constituer des alternatives à la régression d'espèces plus hygrophiles notamment dans des zones plus septentrionales que leurs aires actuelles.

Abies / sapins circum-mediterranéens / écologie / écophysiologie / changements climatiques

\section{INTRODUCTION}

In the scenario of expected climatic change (temperature increases and water deficits) related to the greenhouse effect, questions are being raised concerning the migration of the potential area of forest species (reduction in the south and low altitudes, extension towards the north and higher altitudes) together with the consequences on silviculture. To answer these questions, information on climatic evolution and the ecophysiology of the forest species concerned is required $[15,59]$.

In this context, certain species are of particular interest because of their silvicultural characteristics. For example, in Europe this is the case for circum-Mediterranean firs. These firs have fairly high productivity and, due to their good soil cover, they have a favourable effect on erosion and forest fire control. In certain parts of their present distribution area they could be in danger because of their ecological and ecophysiological characteristics; but they could also be a valuable solution for the replacement of other species in more northerly zones with humid temperate climates which would no longer be adapted to new climatic conditions. Also in this paper we will try to answer the questions on the basis of our knowledge of the ecology and physiology of these firs using a simplified climatic analysis of the original distribution areas.

\section{CIRCUM-MEDITERRANEAN FIRS}

Circum-Mediterranean firs form a group of species that are closely related genetically but occupy disconnected and sometimes limited areas around the Mediterranean. Three groups of species come under this name $[16,17]$ :

- strictly Mediterranean firs: Abies cephalonica Loud, Abies cilicica de Lannoy, Abies marocana Trabut, Abies nebrodensis (Lojac), Abies numidica Carrière and Abies pinsapo Boissier;

- north Anatolian firs: Abies bormulleriana Mattfeld, Abies equi trojani Asch., and Abies nordmanniana Spach;

- Abies alba Mill. Which, as well as northern provenances, includes provenances in the Mediterranean bioclimate, which were the only ones taken into account in this work, and Abies borisii regis Mattf. from central northern Greece and Macedonia which is considered to be an introgressive population between Abies alba and Abies cephalonica.

Variability in genetic characteristics (bud burst, growth, etc.) within the species was identified during an examination of the different provenances [2, 4, 33, 35, 39-44, 53, 68].

In their original ranges, circum-Mediterranean firs cover areas of varying size: Abies numidica covers only a few hundred hectares and A. nebrodensis is represented by about 30 individuals [66] (table I). Some have been introduced

Table I. General data relating to circum-Mediterranean firs.

\begin{tabular}{|c|c|c|c|c|}
\hline Species & Origin area & Surface area (ha) & Maximum heights (m) & Production $\left(\mathrm{m}^{3} / \mathrm{ha} /\right.$ year $)$ \\
\hline Abies alba & France, Spain, Italy, Greece & - & 50 & $5-10$ \\
\hline Abies bornmulleriana & Turkey & 200000 & 50 & $6-14$ \\
\hline Abies cephalonica & Greece & 200000 & 30 & $4-6$ \\
\hline Abies cilicica & Turkey & 350000 & 35 & $2-6$ \\
\hline Abies equi trojani & Turkey & 5500 & 40 & $6-13$ \\
\hline Abies nebrodensis & Italy & - & - & - \\
\hline Abies nordmanniana & Turkey & - & 50 & $9-13$ \\
\hline Abies numidica & Algéria & 300 & 25 & $2-6$ \\
\hline Abies pinsapo & Spain & 1300 & 30 & $1-4$ \\
\hline
\end{tabular}


successfully outside their natural ranges, notably in France. They consist of various types of stand: even-aged high forest, uneven-aged high forest and high forest mixed with other species including beech, cedar, oak and pine. They reach maximum heights of 25 to 50 meters and production varies from 2 to $15 \mathrm{~m}^{3} \mathrm{ha}^{-1} \mathrm{yr}^{-1}$ depending on the species [38] and the site; they produce high quality (table I).

\subsection{General ecology}

These firs are fairly well known with respect to the general ecology of their natural ranges, thanks to work by various authors: $[3,6,7,18,24,27,28,30,31,45,55,57,60-67,70$, $72-76,78,80,81]$. In general, in their natural ranges, apart from A. bornmulleriana which can be found at very low altitudes, these firs grow at altitudes of above $400 \mathrm{~m}$ and some at up to $2400 \mathrm{~m}$ (figure 1). These zones may suffer from severe summer drought but receive abundant precipitation during the autumn and spring. They can be found on different parent materials, calcareous or non-calcareous, but develop best on deeper acid soils with high water reserves.

Although meteorological data is rare in the geographical areas occupied by these species, it is known that they have very high water consumption and seem to be located mainly in humid or even very humid bioclimates characterized by an annual precipitation of $1000 \mathrm{~mm}$ or more. Abies cephalonica and Abies cilicica can develop in a sub-humid climate characterized by a relatively low annual precipitation of between 700 and $800 \mathrm{~mm}$. Except for A. numidica, circum-Mediterranean firs occupy geographical zones with relatively wide mean annual temperature ranges compared with other forest species as shown in figure 2, notably in the case of A. cephalonica, A. bornmulleriana and A. cilicica.

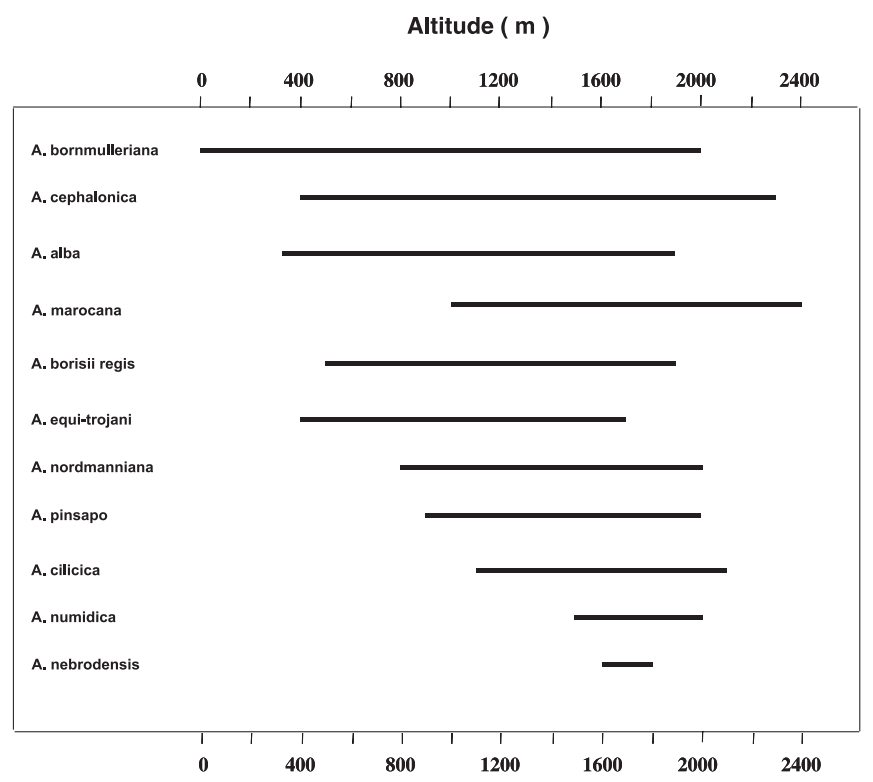

Figure 1. Altitudinal distribution of circum-Mediterranean firs.

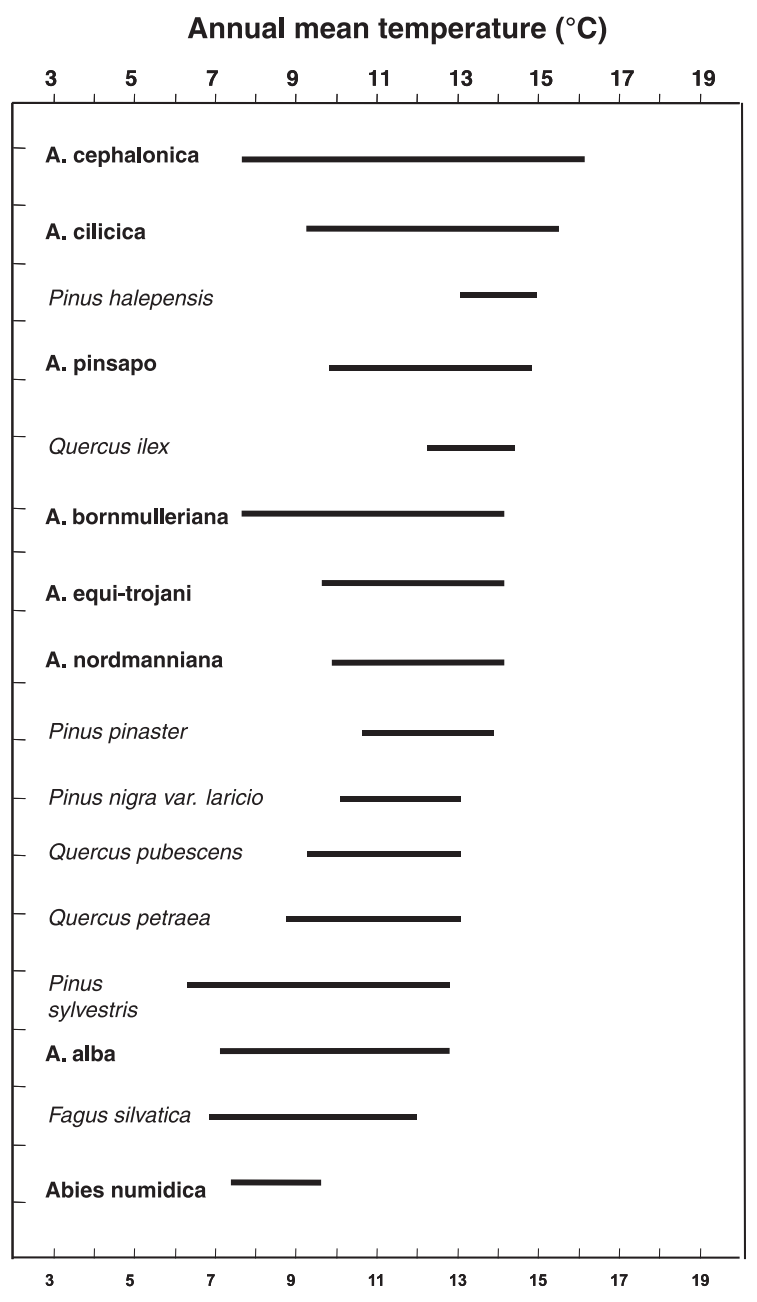

Figure 2. Mean annual temperatures of the natural ranges of the different species of circum-Mediterranean firs, compared with other species.

Natural regeneration of firs is usually easy except at the range boundaries and in certain special situations related to allelopathic phenomena $[19,20]$ or toxicity. Exposure may be a determining factor in general climatic conditions. Regeneration is normally more abundant below a certain level of cover where micro-climatic conditions are more favorable with respect to water supply and temperature $[26,56]$. The risk of late frost damage is reduced to a greater or lesser extent by the presence of cover (shelterbelt, clearing, forest edge) and in some cases by an improvement in the general growth conditions of young firs $[11,46]$. Thus a reduction in the evapo-transpiration potential at a local micro level improves the overall water supply conditions, resulting in plants with a good water status, and therefore better photosynthetic activity and better growth than in an open site [15]. In fact, as long as the water supply conditions in the soil are favorable, the seeds of most firs, except for A. cilicica [25] and A. marocana [19], can develop in zones exposed to strong light conditions $[5,15]$. 
Height growth in firs takes place during a period of 50 to 60 days $[30,31]$ which is defined as short monocyclic growth (figure 3). On average, species which have the earliest bud burst also have early height growth arrest. With respect to bud burst [30], three groups can be distinguished schematically: very early bud burst: Abies cephalonica and Abies cilicica; average bud burst: Abies alba, Abies numidica, Abies marocana, and Abies pinsapo; late bud burst: Abies nordmanniana and Abies bornmulleriana. The difference between the earliest and the latest species may be as great as a month, depending on the year.

Circum-Mediterranean firs have low height growth when young (up to 10-15 years old) compared to other fir species, especially American firs and other species such as Cedar (Cedrus sp.) or Douglas fir for example.

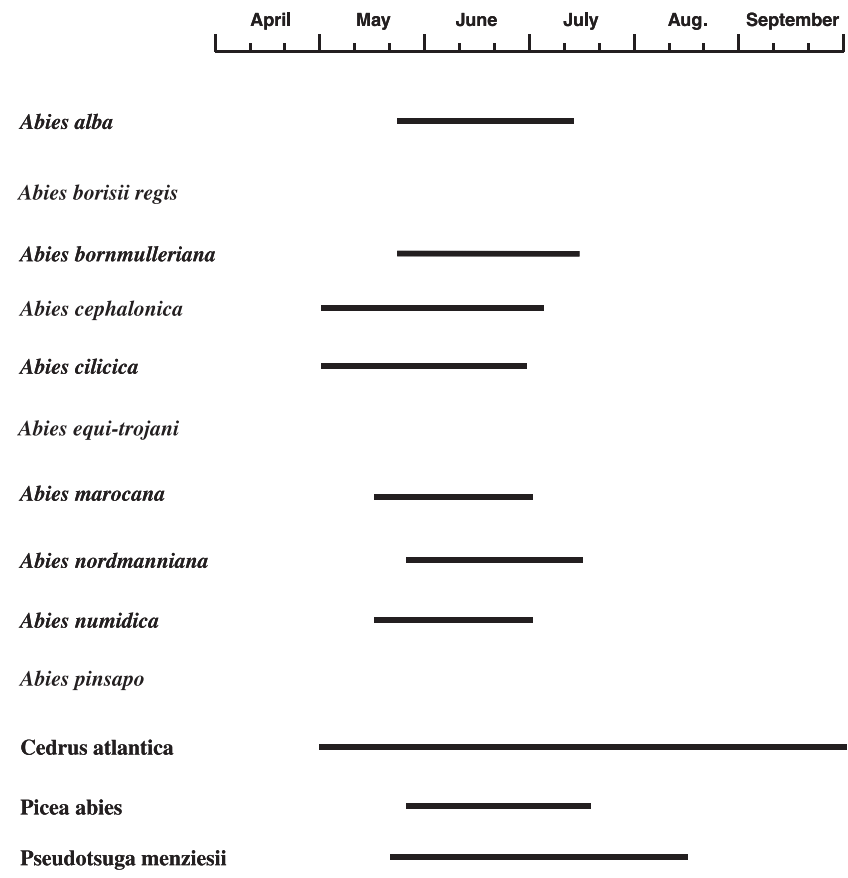

Figure 3. Length of the height growth period of circum-Mediterranean firs and comparison with some other species.

\subsection{Ecophysiology}

\subsubsection{Drought resistance}

Work carried out by different authors: $[12,13,22,23,26$, $33,47,48,50-52,71,72]$, although not covering all species, makes it possible to define the behavior of circum-Mediterranean firs especially in relation to their response to drought. Overall, this research shows that these species are characterized by highly sensitive stomatal regulation in response to water stress and, for certain species, the existence of a very efficient "strategy" for avoiding drought. They also demonstrate the existence of wide variability at the inter- and intra-species level which could be exploited in the field of genetics.

During a severe drought, the water potential of the different species may fall to a greater or lesser extent, depending on more or less efficient stomatal regulation. For example, in figure 4 it can be seen that, during a long period of drought in 1976, the water potential of A. nordmanniana stabilized in the daily and nightly phases at around values of $-1.6 \mathrm{MPa}$, demonstrating the existence of durable equilibrium between transpiration and soil water availability over several days [12].

The water potential, corresponding to a complete blockage of transpiration losses, exhibits large differences depending on the species (table II) [13]. Overall, circum-Mediterranean

Table II. Water potential corresponding to the partial and then total control of transpiration (from Aussenac, 1980).

\begin{tabular}{lcc}
\hline Species & $\begin{array}{c}\text { Partially control of } \\
\text { transpiration }(\mathrm{MPa})\end{array}$ & $\begin{array}{c}\text { Complete control of } \\
\text { transpiration (MPa) }\end{array}$ \\
\hline Abies alba & -1.8 & -4 \\
Abies nordmanniana & -0.9 & -3 \\
Abies marocana & -1.4 & -2.7 \\
Abies pinsapo & -1 & -2.8 \\
Abies numidica & -1.2 & -2.4 \\
Abies cilicica & -1.8 & -2.6 \\
Abies cephalonica & -0.8 & -2.4 \\
\hline
\end{tabular}

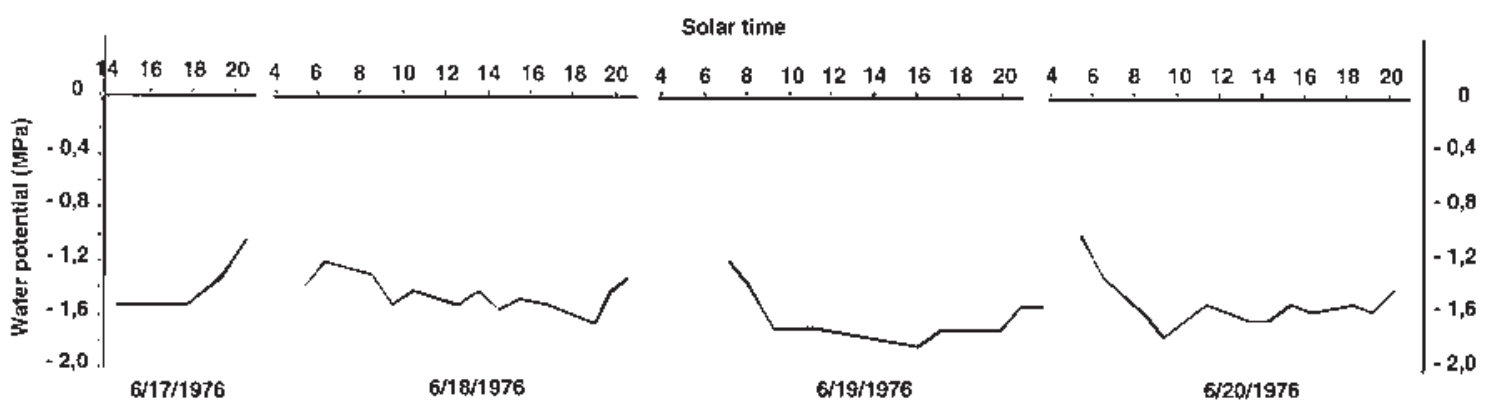

Figure 4. Evolution of the water potential of Abies nordmanniana during a long period of drought in 1976 (from Aussenac and Granier, 1978). 
firs, but A. alba, to a lesser extent exhibit a drought avoidance "strategy" that differs from the tolerance "strategy" observed for Cedrus atlantica and Cedrus libani [14].

There is an increasing gradient of drought resistance, ranging from $A$. alba, from French Mediterranean areas (Aude and Eastern Pyrenees) and probably Italian provenances which are probably better adapted to drought, especially atmospheric drought $[48,50,52]$, than northern provenances, through to A. numidica and A. cephalonica which exhibit the best adaptation via a drought avoidance strategy.

Figures 5 and 6 demonstrate the evolution of net photosynthesis and stomatal conductance under soil drought conditions for A. bornmulleriana and A. cephalonica, which

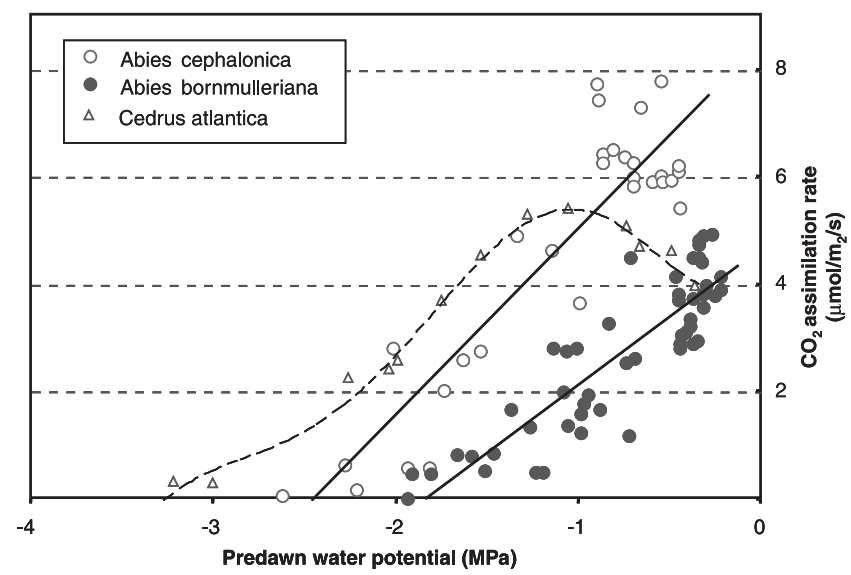

Figure 5. The relationship between the $\mathrm{CO}_{2}$ assimilation rate and predawn water potential for Abies bornmulleriana, Abies cephalonica, and Cedrus atlantica (from Guehl et al., 1991).

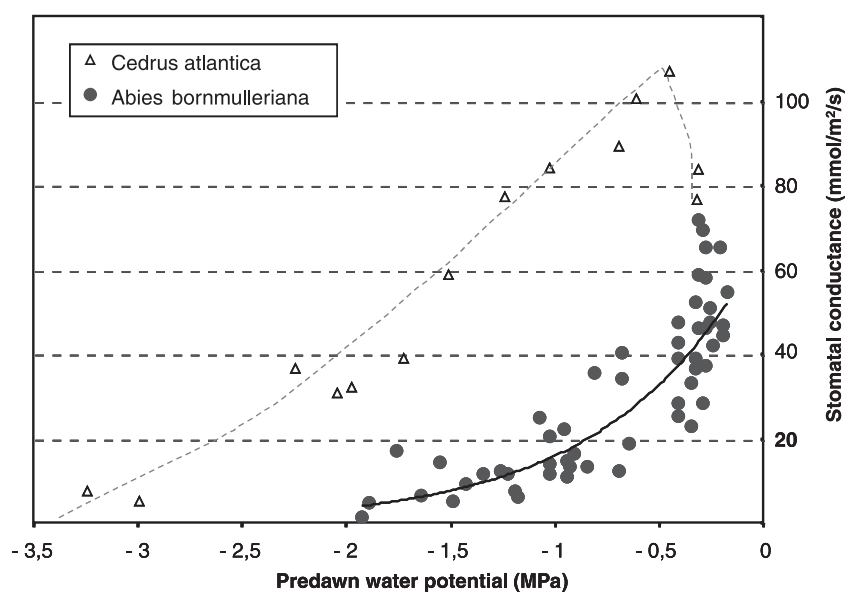

Figure 6. The relationship between stomatal conductance and predawn water potential for Abies bornmulleriana and Cedrus atlantica (from Guehl et al., 1991). become low at predawn water potentials of about -2.0 to $-2.2 \mathrm{MPa}$. Cedrus atlantica, which may occupy identical biotopes behaves very differently (tolerance) and exhibits high photosynthetic activity at much lower predawn water potentials.

\subsubsection{Temperature behavior}

Besides periods of drought, cold is also a factor that should be taken into account to evaluate the possible changes in conditions affecting firs. In winter, photosynthesis is possible for A. alba [49] and probably for other firs down to temperatures of $0{ }^{\circ} \mathrm{C}$. Warming should thus increase photosynthesis during the winter period and play a positive role in improving growth, especially at high altitudes. Firs resist winter frosts well, and the first signs of frost damage (frost crack) only appear in the most sensitive species (A. pinsapo, A. numidica and $A$. cephalonica) at temperatures below $-15^{\circ} \mathrm{C}$. The other firs are resistant to very low temperatures of about $-30{ }^{\circ} \mathrm{C}$.

The resistance level is also a function of the falling temperature conditions in the autumn. In fact, the tolerance of plant tissue to winter cold (hardening) is conditioned by an early, progressive fall in temperature in the autumn. Paradoxically, an increase in temperature in autumn and winter may make some species more sensitive to periods of winter cold. Insufficient hardening combined with a relatively mild climate, but which may involve large, rapid falls in temperature, may result in situations similar to those seen in France in 1985, where serious cold damage was observed in maritime pines in the Landes.

Firs are affected by spring frosts when the buds are in the bud burst phase, and when air temperatures are lower than or equal to $0{ }^{\circ} \mathrm{C}$ [9]. Frost damage depends on the degree of advancement of the different species. Fir bud burst is closely correlated with temperature (the sum of daily temperatures) and with respect to climatic change, an increase in temperature, via a positive influence on early bud burst could worsen the risk of late frost damage, especially for species that are already very early. This damage could jeopardize the development of seedlings and young trees, especially in open zones. The earliest species: A. cephalonica and A. cilicica, could be highly affected by these phenomena which worsen the risk of late frost damage. It is also known that sensitivity to spring frosts is the major obstacle to using A. cephalonica in plantations in the low mountains near the Mediterranean in France [37].

During the summer, in relation with water stress, the increase in temperature can affect the photosynthesis of firs. The effects of such temperature increases are known only for Abies alba [77].

\subsubsection{Growth}

For firs, growth in height does not seem to be particularly influenced by climatic conditions in the current year as it finishes very early (mid-July) before the summer drought 
occurs. Conversely, it is highly dependent on the climatic conditions of the preceding year.

Circumference growth is influenced by current year climatic conditions $[11,69,79]$. It is also known that climatic conditions linked to altitudinal variations influence both circumference growth and wood density [77]. The temperature thresholds for vegetation that regulate growth are only known for A. alba and A. nordmanniana and they are $5.2{ }^{\circ} \mathrm{C}$ and $6.2^{\circ} \mathrm{C}$ respectively [10]. It is reasonable to consider that the vegetation thresholds of other species would be similar to those above. Height growth is correlated with temperature as shown in figure 7 which shows the relationship that exists between the sums daily degrees and the accumulated growth of A. alba and A. nordmanniana [10]. Taking the short growth period into account, there is probably no temperature limitation on height growth, except in high altitude zones where warming could have a positive effect.

Contrary to cedars (Cedrus sp.) [10], this type of height growth does not absorb the inter-annual irregularities in rainfall but seems to be adapted to summer droughts and early cold in the context of a climate that does not vary much from year to year. From this point of view, firs do not seem to be particularly well adapted to climatic change characterized by large inter-annual irregularities in rainfall. Conversely, their tap root system allows them to reach water reserves at deep down having accumulated during the winter period. It is also known that, as from the time of seed germination, firs develop a principal root that penetrates rapidly into the soil [14, 36]. This morphogenetic characteristic is the result of successful adaptation that allows seedlings to resist summer droughts, especially in their first year. In actual fact, worsening drought conditions especially in the spring could affect seedling establishment and jeopardize regeneration and, in

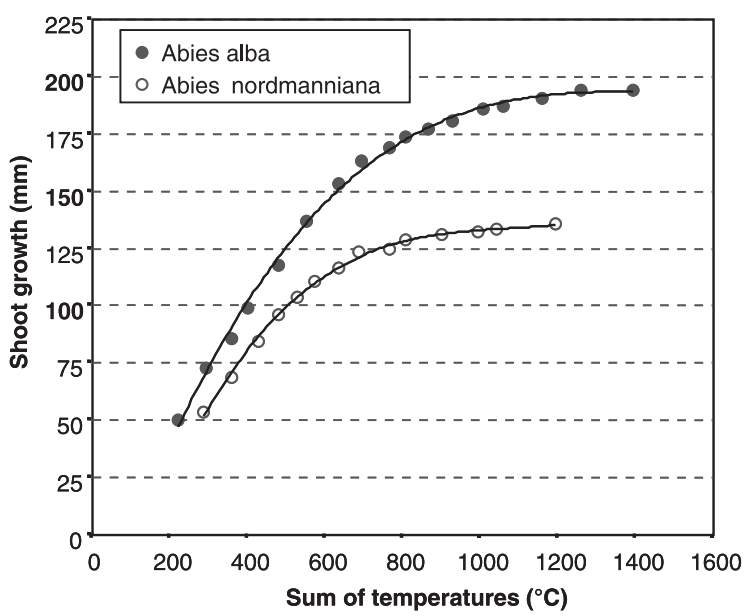

Figure 7. An example of the relationship between annual height growth and sum of temperatures after bud burst (from Aussenac, 1975). the long term, the durability of the stands. Sensitivity to water stress is greater in young seedlings than in older plants.

\section{CLIMATIC CHANGES}

\subsection{Simulation of climatic changes}

Forecasts of future climatic changes are based on general circulation models of the atmosphere (GCMs). According to these studies, by the middle of the century in 2060, with twice the present $\mathrm{CO}_{2}$ concentrations, major climatic changes are foreseen in both thermal and hydric terms. For example, in France [32] there should be a mean temperature increase of $2{ }^{\circ} \mathrm{C}$ or $3{ }^{\circ} \mathrm{C}$, more marked in the summer and in the south of the country, increased precipitation in the winter but a reduction in the summer, with longer, more severe droughts, that should result in lower water availability in the soil. In the south of Europe and North Africa, the temperature and drought increase will be more considerable. Elsewhere the climate would become much more heterogeneous both intraand inter-annually.

As a consequence of these greenhouse effect phenomena, it should be noted that in addition to the characteristic thermal and hydric climatic modifications, there would be the direct effects of increased $\mathrm{CO}_{2}$ on the physiological processes of trees. We do not have any information about such effects on firs. In particular, we do not know what the effect of increased $\mathrm{CO}_{2}$ will be on stomatal regulation and the possible decrease in transpiration observed for other species.

In the natural ranges occupied by circum-Mediterranean firs, climatological data is rare and very incomplete and, under these conditions it is impossible to undertake a detailed climatological study taking into account both intra- and inter-annual variability in temperature and precipitation. Also, due to the diversity and heterogeneity of the climatic descriptions made by the various authors, and to be able to compare different fir species, it seemed interesting to use De Martonne's [29] aridity index:

$$
\mathrm{IA}=\mathrm{P} / \mathrm{T}+10
$$

where $\mathrm{P}$ is annual precipitation in $\mathrm{mm}$ and $\mathrm{T}$ is mean annual temperature in ${ }^{\circ} \mathrm{C}$. The lower the index value, the greater the degree of drought.

The aridity index was calculated for climatological stations situated in the natural range of the species concerned from the climatic data presented by the different authors: [1, $7,8,21,24,25,34,37,40,42,44,53-55,57,58,61,66,67]$.

This very simple annual index, which does not take monthly variations in temperature and precipitation into account, only gives general information on the drought level at the sites considered. Thus it may be considered to be insufficient for use demonstrating the slight differences between Mediterranean bioclimates; in addition, it does not take the soil water reserves into account. 
However, this numerical approach gives one a general comparative view of the climatology of the natural fir ranges under consideration in relation to drought problems. It also simulates climatic changes easily and, for each species, compares them with the present situation.

\subsection{Variation of aridity index}

Figure 8 gives the aridity index (IA0) for the different species where it has been possible to calculate them from the climatic data available. Depending on the species, there are large differences in the range and value of the indices, in relation to the size of the areas and their altitudes. Thus A. numidica, A. nebrodensis and A. pinsapo have high indices due to their positions at high altitudes with very high precipitation and relatively low temperatures. We also note that A. cephalonica, A. cilicica and A. nordmanniana exhibit a range of indices, with the lowest near to 30 . Meanwhile A. alba, A. bornmulleriana, A. equi-trojani, A. marocana, A. pinsapo and A. borisii regis are characterized by an index range with lowest values between 40 to 50 .

So as to simulate the effects of climatic change on drought conditions simply, the aridity indices (IA) were calculated from a mean annual temperature $(\mathrm{T})$ and mean annual precipitation $(\mathrm{P})$ for the following hypotheses:

IA0 (T and P), IA $2\left(\mathrm{~T}+2{ }^{\circ} \mathrm{C}\right.$ and P), IA $3\left(\mathrm{~T}+3{ }^{\circ} \mathrm{C}\right.$ and P), IA4 $\left(\mathrm{T}+4{ }^{\circ} \mathrm{C}\right.$ and $\left.\mathrm{P}\right)$;

IA $2-50\left(\mathrm{~T}+2{ }^{\circ} \mathrm{C}\right.$ and $\left.\mathrm{P}-50 \mathrm{~mm}\right), \mathrm{IA} 2-100\left(\mathrm{~T}+2{ }^{\circ} \mathrm{C}\right.$ and $\mathrm{P}$ $-100 \mathrm{~mm})$, IA2-150 ( $\mathrm{T}+2{ }^{\circ} \mathrm{C}$ and $\left.\mathrm{P}-150 \mathrm{~mm}\right)$;

IA3 $\left(\mathrm{T}+3{ }^{\circ} \mathrm{C}\right.$ and $\left.\mathrm{P}-50 \mathrm{~mm}\right)$, IA $3\left(\mathrm{~T}+3{ }^{\circ} \mathrm{C}\right.$ and $\left.\mathrm{P}-100 \mathrm{~mm}\right)$, IA3 $\left(\mathrm{T}+3{ }^{\circ} \mathrm{C}\right.$ and $\mathrm{P}-150 \mathrm{~mm}$ );

IA4 $\left(\mathrm{T}+4^{\circ} \mathrm{C}\right.$ and $\left.\mathrm{P}-50 \mathrm{~mm}\right)$, IA4 $\left(\mathrm{T}+4^{\circ} \mathrm{C}\right.$ and $\left.\mathrm{P}-100 \mathrm{~mm}\right)$, IA $4\left(\mathrm{~T}+4^{\circ} \mathrm{C}\right.$ and $\left.\mathrm{P}-150 \mathrm{~mm}\right)$.

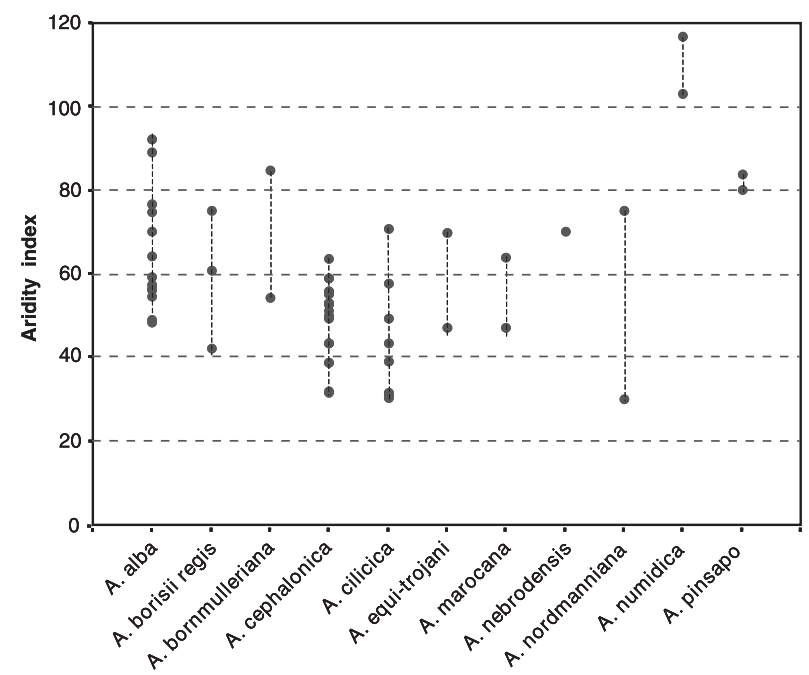

Figure 8. Aridity indices (IA) for the natural ranges of the different species of circum-Mediterranean firs.
Figure 9 shows the range of variation in the lowest aridity indices obtained for the different hypotheses and fir species (concerning A. nordmanniana, we found only two aridity index values in the bibliography without climatic data and it was impossible to calculate the variation in aridity indices). A reduction in the indices can be observed in relation to the increase in temperature and the decrease in rainfall.

For A. numidica, A. pinsapo and A. nebrodensis situated at altitudes with very high indices, a temperature increase and a reduction in precipitation would not have a major effect and should not give rise to an increase in water stress that might hinder their existence in their natural range. If we imagine for these species an increase of water stress with for example anIA of 40 , with a temperature increase of $4{ }^{\circ} \mathrm{C}$, the calculation indicate that the decrease of rainfall reach respectively $53 \%, 42 \%$ and $31 \%$.

It is also possible that $A$. numidica of which the resistance to drought is known from ecophysiological work [13], could develop under conditions that are drier than those of its present range.

For the other drought avoiding species, already in zones characterized by an index, of below 45, this modification could lead to an increase in the duration and degree of water stress, which might result in the disappearance of trees and

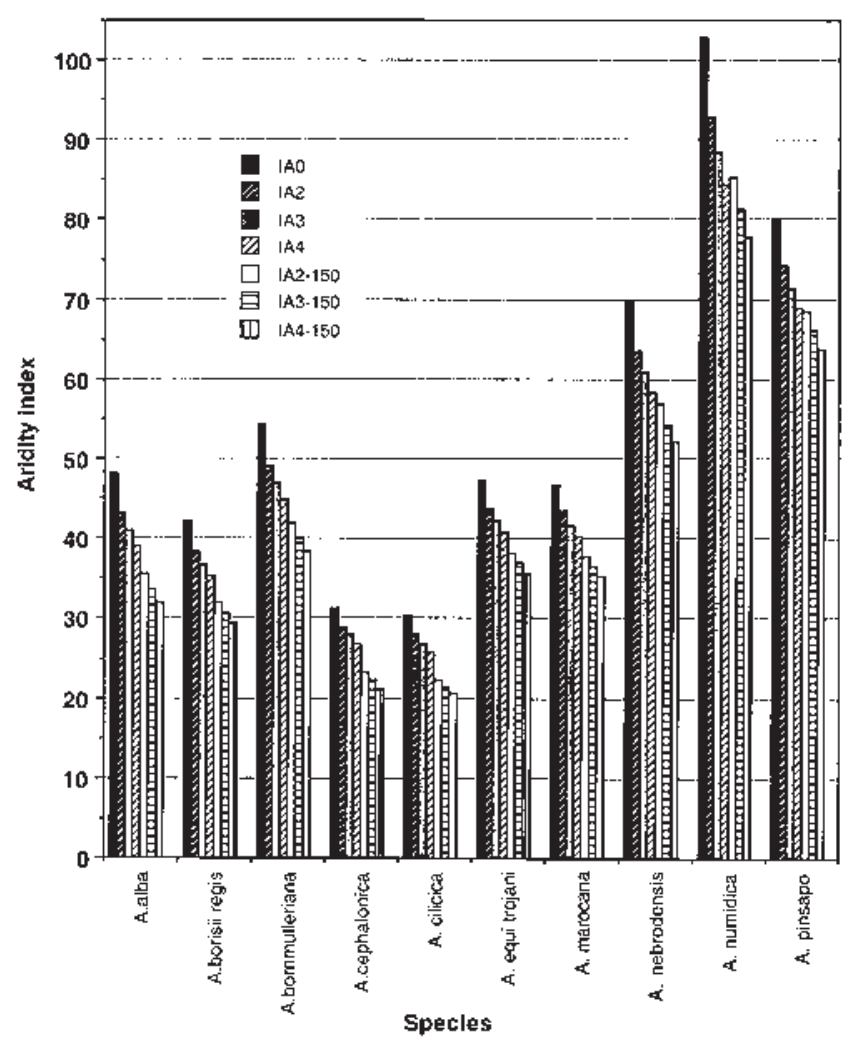

Figure 9. Simulation of variations aridity indices (IA) relative to an increase in mean temperature and a reduction or increase in annual rainfall. 
regression of the ranges concerned. A. cephalonica, A. cilicica, A. nordmanniana and A. boris regis may be particularly affected by such regression phenomena in their natural ranges.

With respect to A. alba, different research results [74] show that below an aridity index of 45 , this species cannot survive except in particular situations where soils have large water reserves or a northerly aspect.

Table III indicates the rainfall increase necessary to maintain the aridity index at its present lowest level, for a $2{ }^{\circ} \mathrm{C}, 3{ }^{\circ} \mathrm{C}$ and $4{ }^{\circ} \mathrm{C}$ temperature increase. The increase in rainfall is necessary for all species with the exception of A. nebrodensis, A. numidica and A. pinsapo. This result is in addition to our knowledge about the ecophysiology of forest trees, i.e. in the case of a hypothetical moderate temperature increase, the species considered would not be greatly disrupted, if the rainfall increases enough. In effect, in France it is regularly observed that northern species can grow

Table III. Rainfall (mm) increase to maintain the aridity index at its present lowest level for different temperature increases.

\begin{tabular}{lcccc}
\hline Species & Aridity index & \multicolumn{3}{c}{ Increase of temperature $\left({ }^{\circ} \mathrm{C}\right)$} \\
& & +2 & +3 & +4 \\
\hline A. alba & 48.2 & 96 & 145 & 193 \\
A. borisii regis & 42.1 & 84 & 127 & 168 \\
A. bornmulleriana & 54.2 & 108 & 163 & 217 \\
A. cephalonica & 31.4 & 63 & 94 & 126 \\
A. cilicica & 30.3 & 61 & 91 & 122 \\
A. equi trojani & 47.1 & 94 & 142 & 188 \\
A. marocana & 46.8 & 94 & 141 & 187 \\
A. nebrodensis & 70.0 & 140 & 210 & 280 \\
A. numidica & 102.9 & 206 & 308 & 412 \\
A. pinsapo & 80.0 & 160 & 240 & 320 \\
\hline
\end{tabular}

successfully in southerly regions as long as the water supply (especially soil water reserves) is large enough in relation to evapotranspiration.

These results and our knowledge of the ecophysiology of circum-Mediterranean firs suggest that those parts of their areas already presenting a low aridity index, especially at low altitudes, could be affected by decline if there should be an increase in temperature without a sufficient increase in rainfall.

\section{CONCLUSION}

In general, it is possible to state that circum-Mediterranean firs are highly water demanding but are characterized by the existence of physiological functions that allow them to avoid drought: the occurrence of annual growth before the summer drought period, and high sensitivity of stomatal regulation to drought. All these points differ from cedar trees, which have developed physiological mechanisms that increase their tolerance to water stress. However, differences exist between the different species of circum-Mediterranean fir.

On the basis of all the different results obtained, and taking ecological and ecophysiological characteristics into account, it seems (table IV) that a possible increase in temperature without an increase in rainfall, would generate a high risk that the present areas of circum-Mediterranean will decrease for all fir species considered (with the exception no doubt of A. numidica and A. pinsapo) in the lowest zones of their ranges but also in other zones with a southerly aspect and very superficial soils.

For A. cephalonica and A. cilicica, species with early bud burst, there is also an increased risk of damage by late frosts in addition to the effects of water stress. With the exception of

Table IV. Synthesis of the possible effects of a temperature increase $\left(\mathrm{T}+2^{\circ} \mathrm{C}\right)$ on circum-Mediterranean firs, and possible uses in the replacement of other species in the case of a hypothetical climatic change.

\begin{tabular}{|c|c|c|}
\hline Species & Possible effects of a temperature increase & Possible uses in the replacement of other species \\
\hline Abies alba & $\begin{array}{l}\text { High risk of decrease of present areas in lowest zones with Aridity index lower than } 45 . \\
\text { Risk of increase of late frost damage }\end{array}$ & - \\
\hline Abies bornmulleriana & Risk of decrease of present area in lowest zones with Aridity index lower than 55 & Valuable solution for the replacement \\
\hline Abies borisii regis & Risk of decrease of present area in zones with Aridity index lower than 45 & - \\
\hline Abies cephalonica & High risk of decrease of present areas in lowest zones with Aridity index lower than 35 & $\begin{array}{l}\text { Valuable solution for the replacement } \\
\text { but risk of late frost damage }\end{array}$ \\
\hline Abies cilicica & Risk of decrease of present areas in lowest zones with Aridity index lower than 35 & $\begin{array}{l}\text { Valuable solution for the replacement } \\
\text { but risk of late frost damage }\end{array}$ \\
\hline Abies equi trojani & Risk of decrease of present areas in lowest zones with Aridity index lower than 50 & - \\
\hline Abies marocana & Risk of decrease of present areas in lowest zones with Aridity index lower than 50 & Possible utilization \\
\hline Abies nebrodensis & Origin area too much restricted, impossibility to have an estimation of the risk of decrease & - \\
\hline Abies nordmanniana & Risk of decrease of present areas in lowest zones with Aridity index lower than 35 & Already used \\
\hline Abies numidica & Limited risk of decrease of present area & Possible utilization but risk of late frost damage \\
\hline Abies pinsapo & Limited risk of decrease of present area & Possible utilization but risk of late frost damage \\
\hline
\end{tabular}


A. nordmanniana and A. bornmulleriana, the other species may be affected as well, but to a lesser degree.

With respect to natural regeneration phenomena in firs, it is difficult to estimate the effect of climate change bearing in mind the uncertainty about the real evolution of climatic parameters and also the complexity of the phenomena involved: flower induction, fertilization, fruiting, seed dispersal, germination and seedling establishment. All these stages may be affected in more or less contradictory ways. In addition, it should be noted that little work has been carried out in these fields, which are nevertheless essential in the understanding of stand evolution processes. Lastly, the possible evolution of natural or potential pests is also unknown.

For the replacement of species, which would become necessary as a result of climatic change, it can be stated that apart from A. nordmanniana which has already been used, these firs (except for A. nebrodensis, due to the small number of trees) could constitute an alternative to the regression of more water demanding species, especially in the more northerly zones than their present ranges. According to this hypothesis the provenances best adapted to drought should be chosen and for the species concerned, the provenances with late bud burst should be favored.

\section{REFERENCES}

[1] Allue Andrade J.L., Atlas fitoclimatico de España. Ministerrio de Agricultura Pesca y Alimentation, Instituto Nacional de Investigaciones Agrarias, $1990,222 \mathrm{p}$

[2] Arbez M., Comportement en pépinière de quelques provenances françaises de sapin. Critique d'une notion traditionnelle, Rev. For. Fr. 21 (1969) 353-361.

[3] Arbez M., Répartition, écologie et variabilité des sapins de Turquie du Nord : Abies nordmanniana Spach, Abies bornmulleriana Mattfeld, Abies equi-trojani Ascherson et Sintenis, Ann. Sci. For. 26 (1969) 257-284.

[4] Arbez M., Étude comparative en pépinière de quelques provenances françaises de sapin pectiné (Abies alba mill.) premier apercu de la variabilité intraspécifique et mise au point sur le «sapin de l'Aude », Ann. Sci. For. 26 (1969) 475-509.

[5] Arista M., Survival of seedlings of Abies pinsapo Boiss. in their natural habitat. (Supervivencia de las plantulas de Abies pinsapo Boiss. en su habitat natural), An. Jard. Bot. Madrid 51 (1994) 193-198.

[6] Arista M., Talavera S., Cone production and cone crop pattern in Abies pinsapo Boiss., (Produccion de pinas y ciclos de cosechas en Abies pinsapo Boiss.), An. Jard. Bot. Madrid 53 (1995) 5-12.

[7] Arista M., The structure and dynamics of an Abies pinsapo forest in southern Spain, For. Ecol. Manage. 74 (1995) 81-89.

[8] Ata C., Silvicultural characteristics of Abies equi-trojani Aschers-Sinten and growth relationships between Pinus nigra Arnold var. pallasoana Endl and Abies equi-trojani in mixed natural forests of Turkey, Forestry 62 (1989) 285-296.

[9] Aussenac G., Observations à propos d'une gelée tardive, Rev. For. Fr. 6 (1968) 431-434.

[10] Aussenac G., Étude de la croissance en hauteur chez quelques résineux : effet de la température, Ann. Sci. For. 32 (1975) 1-16.

[11] Aussenac G., Influences du couvert forestier sur la croissance de quelques résineux dans le jeune âge, Can. J. For. Res. 7 (1977) 8-18.

[12] Aussenac G., Granier A., Quelques résultats de cinétique journalière du potentiel de sève chez les arbres forestiers, Ann. Sci. For. 35 (1978) 19-32.
[13] Aussenac G., Comportement hydrique de rameaux excisés de quelques espèces de sapins et de pins noirs en phase de dessiccation, Ann. Sci. For. 37 (1980) 201-215.

[14] Aussenac G., Le Cèdre, essai d'interprétation bioclimatique et écophysiologique, Bull. Soc. bot. Fr. 131 (1984) 385-398.

[15] Aussenac G., Interactions between forests stands and microclimate: ecophysiological aspects and consequences for silviculture, Ann. For. Sci. 57 (2000) 287-301.

[16] Barbero M., Quezel P., Les forêts de sapin sur le pourtour méditerranéen, Ann. Inst. Bot. Cavanilles 32 (1975) 1245-1289.

[17] Barbero M., Quezel P., Les forêts de Méditerranée orientale dans une perspective d'écologie appliquée à la sylviculture méditerranéenne, Acta Oecol. 2 (1981) 227-239.

[18] Baumer M., Le sapin du Maroc, Rev. For. Fr. 20 (1977) 343-354.

[19] Becker M., Drapier J., Rôle de l'allélopathie dans les difficultés de régénération du sapin (Abies alba Mill.) Acta Oecol. 5 (1984) 347-356.

[20] Becker M., Drapier J., Rôle de l'allélopathie dans les difficultés de régénération du sapin (Abies alba Mill.) II. Étude des lessivats naturels de feuillage, de litière et d'humus, Acta Oecol. 6 (1985) 31-40.

[21] Boskos L., Quelques données dendrométriques sur les peuplements de sapin (Abies cephalonica Loud.) au Mainalon en Péloponnèse (Grèce), Rev. For. Fr. 48 (1996) 271-278.

[22] Bouachrine J., Étude comparée de l'influence de la sécheresse atmosphérique sur les échanges gazeux chez cinq espèces de sapins méditerranéens : A. alba, A. cephalonica, A. marocana, A. numidica, A. nordmanniana, Mémoire D.E.A., Nancy, 1985, 37 p.

[23] Bouachrine J.E., Contribution à la caractérisation écophysiologique de quelques sapins méditerranéens : réponses des échanges gazeux foliaires à la sécheresse atmosphérique et édaphique, Thèse en Biologie végétale et Forestière, Université Nancy I, 1992, 118 p.

[24] Bozkus H.F., Ecological characteristics of the Taurus fir (Abies cilicica Carr.), in: Ducrey M., Oswald H. (Éds.), Séminaire international Sapins méditerranéens : adaptation, sélection et sylviculture, CCE Luxembourg, 1990, pp. 163-172.

[25] Caliskan A., Growth patterns and silvicultural treatments in mixed Pinus sylvestris/Abies bornmulleriana/Fagus orientalis stands in the Buyukduz experimental forest, Istanbul Universitesi Orman Fakultesi Dergisi SeriA, 42 (1995) 183-210.

[26] Cochard H., Vulnerability of several conifers to air embolism, Tree Physiol. 11 (1992) 73-83.

[27] Colombet M., Écologie des sapins méditerranéens en Provence et en Languedoc, Mémoire de $3^{\mathrm{c}}$ année ENITEF, 1984, 109 p.

[28] Dafis S., Traitements sylvicoles des sapinières en Grèce, in: Ducrey M., Oswald H. (Éds.), Séminaire international sapins méditerranéens : adaptation, sélection et sylviculture, CCE Luxembourg, 1990, pp. 243-256.

[29] De Martonne E., L'indice d'aridité, Bulletin de l'Association des géographes français, 9 (1926) 3-5.

[30] Debazac E.F., Observations sur le débourrement et la croissance en longueur de quelques espèces de sapins, Rev. For. Fr. 2 (1965) 120-130.

[31] Debazac E.F., Claude M.E., Nouvelles observations sur le débourrement et la croissance en longueur de quelques espèces de sapins, Rev. For. Fr. 3 (1967) 183-190.

[32] Déqué M., Modélisation numérique des impacts climatiques, in: Ministère de l'Environnement, Mission interministérielle de l'effet de serre, Paris, Impacts potentiels du changement climatique en France au $\mathrm{XXI}^{\mathrm{e}}$ siècle, Seconde édition, 2000, pp. 22-45.

[33] Descroix L., Variabilité génétique du sapin de Grèce et du sapin de nordmann. Étude comparée de leur comportement hydrique avec le cèdre de l'Atlas, Mémoire $3^{\mathrm{c}}$ année, ENITEF, 1981, 135 p.

[34] Ducci F., Silver fir (A. alba Mill.) of central-southern apennines morphometrical variability in 1 year old seedlings, in: Ducrey M., Oswald H. (Éds.), Séminaire international sapins méditerranéens : adaptation, sélection et sylviculture, CCE Luxembourg, 1990, pp. 59-76.

[35] Ducci F., Proietti R., Favre J.M., Allozyme assessment of genetic diversity within the relic Sicilian fir Abies nebrodensis (Lojac.) Mattei, Ann. For. Sci. 56 (1999) 345-355. 
[36] Ducrey M., Joffre M.C., Menoud M.A., Croissance racinaire et reprise en plantation du sapin de Céphalonie, in: Ducrey M., Oswald H. (Éds.), Séminaire international sapins méditerranéen : adaptation, sélection et sylviculture, CCE Luxembourg, 1990, pp. 227-240.

[37] Ducrey M., Turrel M., Résultats au bout de 9 ans d'une plantation expérimentale de sapin de Céphalonie dans les Alpes-de-Haute-Provence, Forêt méditerr. XIX (1998) 168-181.

[38] Fabbio G., Productivity and treatment of the silver fir stand on Monte Faeto, Calabria (Produttivita e trattamento dell'abetina del monte Faeto in Calabria Montanaro d'Italia), Monti e boschi 30 (1979) 37-44.

[39] Fady B., Croissance du sapin de Grèce : variabilité inter-provenances dans trois stations méditerranéennes françaises, Ann. Sci. For. 45 (1988) 239-253.

[40] Fady B., Genetic variability of height growth components of the greek fir (Abies cephalonica), Can. J. For. Res. 20 (1990) 1453-1460.

[41] Fady B., Étude de la variabilité du débourrement végétatif du sapin de Céphalonie en plantation, Ann. Sci. For. 48 (1991) 73-85.

[42] Fady B., Variabilité géographique et estimation des paramètres génétiques de la croissance en hauteur de jeunes sapins de Céphalonie, Ann. Sci. For. 48 (1991) 279-295

[43] Fady B., Effect of osmotic stress on germination and radicle growth in 5 provenances of Abies cephalonica Loud., Acta Oecol. 13 (1992) 67-79.

[44] Fady B., Caractéristiques écologiques et sylvicoles des sapins de Grèce dans leur aire naturelle et en plantation dans le Sud de la France. Perspectives pour le reboisement en région méditerranéenne, Rev. For. Fr. 45 (1993) 119-133.

[45] Giacobbe A., Natural regeneration of silver fir in the Apennins (La rinnovazione naturale dell' abete appenninico), Ann. Accad. Ital. Sci. For. 18 (1969) 227-289.

[46] Giannini R., Comportamento di semenzali di abete bianco di diversa provenienza a vari gradi di ombreggiamento, Ital. For. Montana. 28 (1973) $20-26$.

[47] Granier A., Colin F., Effets d'une sécheresse édaphique sur le fonctionnement hydrique d'Abies bornmulleriana en conditions naturelles, Ann. Sci. For. 47 (1990) 189-200.

[48] Grieu P., Guehl J.M., Aussenac G., The effect of soil and atmospheric drought on photosynthesis and stomatal control gas exchange in three coniferous species, Physiol. Plant. 78 (1988) 97-104.

[49] Guehl J.M., Étude comparée des potentialités hivernales d'assimilation carbonée de trois conifères de la zone tempérée (Pseudotsuga menziesii mirb., Abies alba Mill. et Picea excelsa link), Ann. Sci. For. 42 (1985) 23-38.

[50] Guehl J.M., Aussenac G., Photosynthesis decrease and stomatal control of gas exchange in Abies alba mill. in response to vapor pressure difference, Plant Physiol. 83 (1987) 316-322.

[51] Guehl J.M., Bouachrine J., Zimmermann R., Dreyer E., Responses of photosynthesis and stomatal conductance to atmospheric humidity in some mediterranean Abies species, Ann. Sci. For. 46 (1989) 401-405.

[52] Guehl J.M., Aussenac G., Bouachrine J., Zimmermann R., Pennes J.M., Ferhi A., Grieu P., Sensitivity of leaf gas exchange to atmospheric drought, soil drought, and water-use efficiency in some Mediterranean Abies species, Can. J. For. Res. 21 (1991) 1507-1515

[53] Guidi G., Pelleri F., First observations on two trial plantations of Greek fir in the central southern Appennines (Prime osservazioni su due impianti sperimentali di abete greco dell'appennino centro meridionale), Ann. Ist. Sper. Selvic. 21 (1992) 109-134.

[54] Hetsch W., Vergos S., Beech forests of the northern Pindos Mountains, Greece (Die Buchenwalder des Nord-Pindos), Forstarchiv. 68 (1997) 10-18.

[55] Ignesti S., Paci M., Natural regeneration of silver fir in the Vallombrosa forest, Ann. Accad. Ital. Sci. For. 38 (1989) 541-584.

[56] Iovino F., Menguzzato G., Veltri A., Studio delle Condizioni Termoigrometriche Dell'Aria e del Suolo nelleAbetine di Serra san Bruno, Ann. Accad. Ital. Sci. For. 37 (1988) 1-44.

[57] Kolai L., La sapinière à Abies numidica dans le mont Babor : phytosociologie et production, Ann. Rech. for. Algérie, $2^{\mathrm{e}}$ semestre (1992) 85-99.

[58] Kramer W., Études et observations sur l'écologie des sapins méditerranéens, in: Ducrey M., Oswald H. (Éds.), Séminaire international sapins mé- diterranéens : adaptation, sélection et sylviculture, CCE Luxembourg, 1990, pp. 195-204.

[59] Lebourgeois F., André Granier A., Bréda N., Une analyse des changements climatiques régionaux en France entre 1956 et 1997. Réflexions en termes de conséquences pour les écosystèmes forestiers, Ann. For. Sci. 58 (2001) 733-754.

[60] Lebtahi F., Bouguedoura N., Le sapin de Numidie, Forêt Algérienne 3 (2000) 39-42.

[61] M'Hirit O., Étude écologique et forestière des cédraies du rif marocain, Ann. Rech. For. Maroc. 22 (1982) 502 p.

[62] M'Hirit O., Les communautés végétales de la sapinière du rif marocain, in: Ducrey M., Oswald H. (Éds.), Séminaire international sapins méditerranéens: adaptation, sélection et sylviculture, CCE Luxembourg, 1990, pp. $135-150$.

[63] Magini E., Research on natural regeneration factors of silver fir in the Apennins (Ricerche sui fattori della rinnovazione naturale dell'abete bianco sull'Apennino), Ital. For. Montana. 22 (1967) 261-270.

[64] Mayer H., Mediterranean mountain fir species and their importance in species trials in Central Europe (Mediterran-montane Tannen-Arten und ihre Bedeutung fur Anbauversuche in Mitteleuropa), Cbl. ges. Forstwesen. 98 (1981) 223-241.

[65] Mayer H., Waldbauliche Probleme in Gebirgswaldern des Maghreb (Nordafrika), Cbl. ges. Forstwesen. 100 (1983) 1-16.

[66] Morandini R., Ducci F., Menguzzato G., Abies nebrodensis (Lojac) Mattei, Inventario 1992, Ann. Ist. Sper. Selvic. 22 (1994) 5-51.

[67] Ozalp G., Range, ecological, silvicultural and growth characteristics of Abies equi-trojani Aschers. et Sint. and Abies bornmulleriana Mattf. in: Ducrey M., Oswald H. (Éds.), Séminaire international sapins méditerranéens : adaptation, sélection et sylviculture, CCE Luxembourg, 1990, pp. 283-294.

[68] Panetsos K.P., Variation in the position of resin canals in the needles of Abies species and provenances, Ann. Sci. For. 49 (1992) 253-260.

[69] Parker A.J., Parker K.C., Faust T.D., Fuller M.M., The effects of climatic variability on radial growth of two varieties of sand pines (Pinus clausa) in Florida, USA, Ann. For. Sci. 58 (2001) 333-350.

[70] Pauly D., Aperçu sur l'écologie d'Abies cephalonica et ses hybrides, Rev. For. Fr. 8-9 (1962) 755-769.

[71] Pennes J.M., Répercussions de la sécheresse édaphique sur l'état hydrique et les échanges gazeux d'un sapin de Nordmann : Abies bornmullerria$n a$, DAA, École Nationale Supérieure d'Agronomie et d'Industrie Alimentaire, 1989, 26 p.

[72] Ping L., Écophysiologie et réaction à la sécheresse de trois espèces de conifères : effet de l'âge, Thèse de doctorat, Université Nancy 1, U.F.R. et S.T.B., G.F.D. Sciences du bois, Biologie Végétale et Forestière, 1992, 116 p.

[73] Quezel P., Les forêts du pourtour méditerranéen, forêts et maquis méditerranéens : écologie, conservation et aménagement, Notes techniques du MAB 2 (1976) 9-34.

[74] Quezel P., La région méditerranéenne française et ses essences forestières. Signification écologique dans le contexte circum-méditerranéen, Forêt Méditerr. 1 (1979) 7-18.

[75] Quezel P., Biogéographie et écologie des conifères sur le pourtour méditerranéen, in: Masson éd., Actualités d'écologie forestière, Pesson, 1980.

[76] Quezel P., Les sapins du pourtour méditerranéen, Forêt Méditerr. VII (1985) 27-34.

[77] Robakowski P., Montpied P., Dreyer E., Temperature response of silver fir (Abies alba Mill.) seedlings, Ann. For. Sci. 59 (2002) 163-170.

[78] Rol R., Contribution à l'étude de la répartition du sapin (Abies alba Mill.), Ann. Ec. Nat. Eaux Forêts VI (1937) 237-290.

[79] Splechtna B.E., Dobry J., Klinka K., Tree-ring characteritics of subalpine fir (Abies lasiocarpa ((Hook. Nutt.)) in relation to elevation and climatic fluctuations, Ann. For. Sci. 57 (2000) 89-100.

[80] Thomas A.L., Gegout J.C., Landmann G., Dambrine E., King D., Relation between ecological conditions and fir decline in a sandstone region of the Vosges mountains (Northeastern France), Ann. For. Sci. 59 (2002) 265-273.

[81] Tocci A., Ducci F., Veracini A., Firs of the Pontus region. (Gli abeti pontici), Ann. Ist. Sper. Selvic. 21 (1992) 135-145. 